\title{
Role of Youth in a Post-Covid World
}

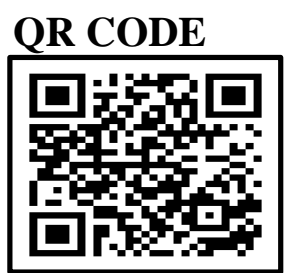

\section{RIYA DUWAL SHRESTHA ${ }^{D}$}

COVID-19 has been affecting the world beyond expectations for almost two years now and this pandemic has taken a heavy toll on people's physical, mental and economic stability. Times of distress like these demand the consolidated effort of all age groups. Particularly, young people have emerged as an active age group, they have shown great efforts as first-line responders, researchers, and volunteers to respond and mitigate many consequences of this epidemic.

History reveals to us that young people have offered a major contribution to every development and revolution of their country and it is widely acknowledged that participation of youth as leaders and active members brings about unprecedented results in achieving health goals. As the health crisis continues to escalate worldwide, the role of youth is indispensable in the post-COVID-19 era. They can contribute to recovery efforts and lead their community back to normalcy.

In the world facing the fright of pandemic, people not only have to fight COVID-19 but also misinformation and misconception that come with it. Above it all, lies a greater battle of finding tranquility amid chaos. Health workers and survivors of this pandemic are battling stigmatization and discrimination due to misinformation about the virus. Such ruthless treatment can mentally affect those with the disease as well as their caregivers. This stigma about COVID-19 will only drive a person away from getting screened, tested, and treated, which has severe public health implications. ${ }^{1}$ Elimination of these misconceptions is very important for postCOVID-19 recovery. So, young people can spread community awareness, share authentic information and dismantle myths regarding COVID-19 both online and offline to stop perpetuating negative labels against survivors and health workers. An emblematic example comes from a Youth choir named Ndlovu Youth Choir in South Africa, where they performed and filmed a musical rendition of the World Health Organization's (WHO) coronavirus safety advice to spread community awareness and avoid unverified information. ${ }^{2}$

Health care workers are globally in high demand, young people can take initiative to ease pressure on frontline workers and find opportunities to give to their community as volunteers. Volunteering will not only support those who require help but will also give young volunteers a sense of meaning and optimism. Many young people around the world have responded by working through these real challenges and making meaningful changes. Josh St John James, 17 from Kingston in London who set up a volunteer group to help out the elderly ensuring that the vulnerable are neither hopeless nor helpless is the quintessence of how youth can radiate positivity and a sense of security during the pandemic. ${ }^{3}$ Hami Nepal Youth Organization, a non-profit organization from Nepal working relentlessly to save countless lives through the distribution of critical supplies for both the healthcare sector and the wide population to fight this virus shows a great example of youth involvement. ${ }^{4}$

Another critical aspect of combating coronavirus is research. Hamza Meghari of Palestine, a Clinical Care Research Assistant currently based in the UK, is conducting a study of clinical and epidemiological characteristics of COVID-19 in association with the World Health Organization (WHO). Researches like this not only help us understand the nature of the virus better but are capable of preventing its further spread and bringing better management tactics. ${ }^{5}$

The World Health Organization (WHO) defines health as "a state of complete physical, mental and social wellbeing and not merely the absence of disease or infirmity" (WHO, 1948). Lockdown protocol has helped in reducing the spread of the virus. However, these restrictive measures have 
harshly affected the mental health of individuals. ${ }^{6}$

It has caused anxiety, disruption, stress, and stigma in society. As the world recovers, youth can contribute by understanding the psychological stress caused by the virus and increase efforts in helping their community. They can continue to advocate for mental wellbeing and be someone to whom others can turn for psychological support. Focusing on the maintenance of mental health, public awareness campaigns can be organized in this prevailing situation. Young family members should take some time to converse with older members of the family and become more involved in their daily activities whenever possible.

Writing about the roles youth have to play in this time of the pandemic, it is an undeniable fact that young people have significantly been affected and it is compounding the already uncertain future of young people. The International Labour Organization (ILO) estimates that more than one in six young people have stopped working due to the pandemic. $^{7}$

Despite the extreme circumstances, young people are using their creative and innovative energy to fight against the crisis and return their community to normalcy. We need youth leadership now more than ever and as changemakers, they play a crucial role in ensuring people that the health plans and the developmental goals are resilient as we take the path of recovery in this post-COVID-19 era.

\section{REFERENCES}

1. Akoto, B. Stigma and scars of coronavirus. Your Commonwealth (Online Article). Available from: https://www.yourcommonwealth.org/socialdevelopment/health-safety-wellbeing/stigma-andscars-of-coronavirus/ [Last Accessed on $12^{\text {th }}$ May, 2021]

2. Wickramanayake, J. Meet 10 young people leading the COVID-19 response in their communities. Africa Renewal (United Nations, Online Article). Available from: $\quad$ https://www.un.org/africarenewal/webfeatures/coronavirus/meet-10-young-people-leadingcovid-19-response-their-communities. [Last Accessed on $12^{\text {th }}$ May, 2021]

3. O'Shea, J. Coronavirus: Volunteers rally round to help those self-isolating. BBC News. (Online Article). Available from: https://www.bbc.com/news/ukengland-51821470 [Last Accessed on $12^{\text {th }}$ May, 2021] 4. Badal, P. Admirable work by Hami Nepali Youth Organization during COVID crisis. Inform Nepal. (Online Article). Available from: https://informnepal.com/exemplary-work-of-haminepali-youth-organization-for-the-betterment-of-thecommunity/ [Last Accessed on 30 ${ }^{\text {th }}$ May, 2021]

5. Women Deliver. 10 Ways Young People are Leading the Way Against COVID-19. (Online Article). Available from: https://womendeliver.org/2020/10ways-young-people-are-leading-the-way-againstcovid-19/[Last Accessed on $30^{\text {th }}$ May, 2021]

6. Nicolás ES. WHO warning on lockdown mental health. EU observer. (Online Article). Available from: https://euobserver.com/coronavirus/147903 [Last Accessed on $30^{\text {th }}$ May, 2021]

7. International Labour Organization (ILO). ILO Monitor: COVID-19 and the World of Work. Fourth Edition. (Online PDF). Available from: https://www.ilo.org/wcmsp5/groups/public/--dgreports/--dcomm/documents/briefingnote/wcms 745963.pdf [Last Accessed on 30 ${ }^{\text {th }}$ May, 2021] 